\title{
Dynamics of Adult and Larval Dungeness Crabs: Larval Abundance as an Indicator of Adult Abundance in Regional Populations
}

\author{
Won-Gyu PARK ${ }^{\dagger}$ \\ (Pukyong National University)
던저네스 게 성체와 유생의 역학: 지역 개체군 지표로서의 유생의 풍도
박 원 규 ${ }^{+}$
(부경대학교)

\begin{abstract}
The relationship between adult abundance and zoea I (ZI) density of Dungeness crabs was investigated in southeastern Alaska. Commercial harvest data (catch per pot) for male crabs larger than $165 \mathrm{~mm}$ in carapace width were collected from the Alaska Department of Fish and Game (ADF\&G) management area, district 114 and a subdivision of district 114, 114C from 1996 to 2003. Commercial harvests of Dungeness crabs in the management area varied interannually. Commercial harvests decreased until 2000 but increased beginning in 2001. ZI density was obtained from zooplankton samples collected monthly from sampling stations within the same management district from 1997 to 2004 . ZI occurred mostly in May and June, but as late as July in 1997 and 2002. ZI densities increased beginning in 1999. Total densities of ZI were significantly correlated with the commercial harvest data of adult male crabs within the management area, 114C (tens of square kilometers), containing the plankton sampling stations, but were not related to total commercial harvests within the larger geographic management area 114 (hundreds of square kilometers). We suggest that larval density may be an indicator of abundance of adult populations of Dungeness crabs.
\end{abstract}

Key words : Larval abundance, Biological indicator, Adult abundance, Dungeness crabs, Adult-larval relationships

\section{I . INTRODUCTION}

The relationship between adult and larval abundance of marine organisms has been a topic of considerable interest because the supply and distribution of dispersing larval phases control the distribution and abundance of populations of benthic adults (Lipcius \& Stockhausen, 2002; Largier, 2003; Levin, 2006). Commercially important species have been the principle topics of the study (Lipcius \& Stockhausen, 2002).

\footnotetext{
† Corresponding author : 051-629-5928, wpark@pknu.ac.kr
} 
The Dungeness crab, Cancer magister is distributed along the west coast of North America from the Aleutian Islands and Pribilof Islands, Alaska to Magdalena Bay, Mexico (Hart, 1982; Jensen, 1995) and supports a valuable commercial fishery throughout their range. Although the species has a broad latitudinal range, the dispersal of adult and juvenile Dungeness crabs is limited because they have limited movements. Tagged crabs were recaptured within a few kilometers of the release area off the coast of California (Gotshall, 1978), within tens of kilometers off the coast of Oregon (Snow \& Wagner, 1965) and within10 $\mathrm{km}$ in southeastern Alaska (Stone \& O'Clair, 2001).

However, Dungeness crab larvae disperse long distances. Larvae can be transported for hundreds of kilometers along coast lines (Phillips, 1988; Jamieson \& Armstrong, 1991; Jamieson \& McConnaughey et al., 1992, 1994; Park et al., 2007), or dispersed offshore for hundreds of km (Lough, 1976; Reily, 1983). Despite the long distance larval dispersal, most early stage larvae are found near parental populations, whereas later stages occur at increasingly longer distances from hatching areas (Lough, 1976; Reilly, 1983). In particular, zoeae I (ZI) occur within tens of kilometers from the hatching locations. Thus, the abundance of ZI may be a surrogate for larval production by the local based parental populations.

The commercial fishery for Dungeness crabs removes a large portion of legal sized male crabs from the population. In some years, more than $90 \%$ of legal sized male crabs were removed from the population in northern
California (Gotshall, 1978; Methot \& Botsford, 1982; Hankin et al., 1997) and British Columbia (Smith \& Jamieson, 1989). Also, in southeastern Alaska, substantial portion of the legal male crabs is also harvested (Taggart et al., 2004). Because of the current fishery regulations, only male crabs larger than $165 \mathrm{~mm}$ in carapace width, not including the ninth anteriolateral spine in Alaska can be harvested; harvests of female and sublegal sizes are prohibited (Rumble \& Bishop, 2003). Intense harvest on legal male crabs reduces 2-25\% of egg production (Hankin et al., 1997) and larger females may lose mating opportunities resulting in lost egg production (Smith \& Jamieson 1991). Since a large portion of legal sized male crabs that are harvested belongs to a single year class (Koeneman, 1985), commercial harvests of Dungeness crabs were proposed as a useful index of year class recruitment (Cleaver, 1949). Although unexploited females produce the actual larvae (McKelvey et al., 1980), commercial harvests of male crabs of legal size may represent the potential reproductive capacity of the population. However, little research about the relationship between larval production and adult abundance has been conducted.

This study explores the relationships between larvae and adult populations of Dungeness crabs in southeastern Alaska. In particular, this study provides evidence that ZI density can be an estimator of relative adult population abundance in Dungeness crabs.

\section{MATERIALS AND METHODS}




\section{Adult indices}

Commercial harvests of Dungeness crabs in the Alaska Department of Fish and Game (ADF \& G) management area, District 114 [Fig. 1] were obtained from Rumble and Bishop (2003) and the ADF\&G (Unpubl. data, Jan Rumble, Douglas, Alaska; Joe Stratman, Petersberg, Alaska) from 1996 to 2003. District 114 includes Cross Sound (main body of subdivision 114A), Glacier Bay (main body of subdivision 114B) and Icy Strait (main body of subdivision 114C); Dungeness crab larvae were collected in this latter subdivision [Fig. 1].

The total commercial harvest from the previous April to March of the year was regarded as total harvest of the larval sampling year. The Dungeness crab fishery is a limited entry fishery within Alaska and the number of permits did not vary over the course of the investigation.

\section{Larval indices}

Zooplankton were collected monthly at four stations in Icy Strait [Fig. 1], aboard the NOAA vessel, John N. Cobb during the latter 10-11 days of each month during May and August 1997-2004 as a part of SouthEast Coastal Monitoring (SECM) Survey by Auke Bay Lab, NOAA. All samplings occurred during daylight, between 0700 and 2000 hours, Alaska Standard Time. A double bongo net with a $60 \mathrm{~cm}$ diameter frame fitted with 505 and $333 \mu \mathrm{m}$ mesh nets was used with a double oblique tow at each station to a depth of $200 \mathrm{~m}$, or within $10 \mathrm{~m}$ of the bottom in the station. Of these, only samples collected with the $333 \mu \mathrm{m}$ mesh net were processed, as not

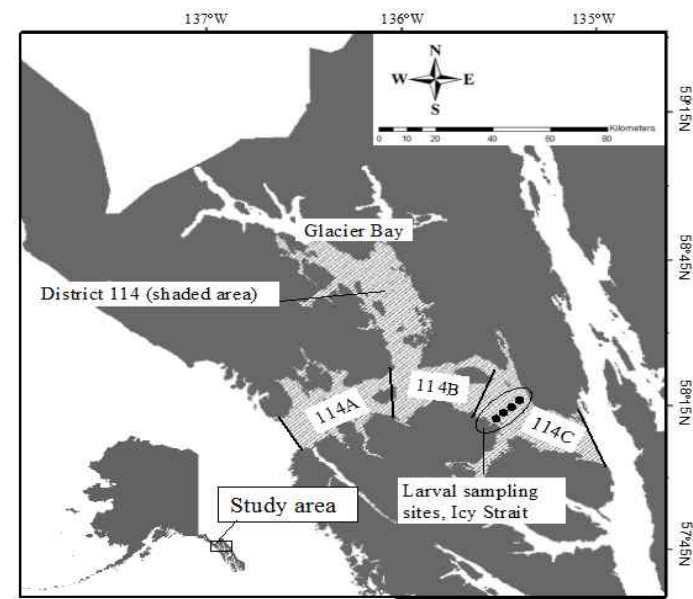

[Fig. 1] Map of study area. Alaska Department of Fish and Game District 114 (shaded), subdivisions of the district 114, 114A, $114 \mathrm{~B}$, and $114 \mathrm{C}$, were indicated on the map. Larval Dungeness crabs were collected by South East Coastal Monitoring (SECM) survey in Icy Strait within subdivision $114 \mathrm{C}$.

all zoea I (ZI) are retained within the larger mesh size. A General Oceanics model 2031, or Rigosha flow meter was installed inside the nets for the calculation of filtered water volumes. Plankton samples were preserved in $5 \%$ neutral formalin aboard the vessel and transported to the lab where Dungeness crab larvae were sorted and ZI were identified, following Poole (1966). ZI density of Dungeness crabs were calculated as individuals per $100 \mathrm{~m}^{3}$, using the filtered water volumes. The total densities of ZI of the year that were collected at four stations in the Icy Strait transect were used for the analysis (see Park, 2007; Park \& Shirley, 2005, for additional details).

3. Statistical analysis 
Total ZI densities from 1997 to 2004 were compared with commercial harvest data from 1996 to 2003 at the district 114 and $114 \mathrm{C}$ of ADF\&G management area using Pearson's product-moment correlation coefficient. For the comparison, a one-year lag was applied because mating and egg extrusion of Dungeness crabs in southeastern Alaska occur in September to November in the previous year and ZI hatch the following spring, such that adult data in the previous year were compared with ZI density of the sampling year. All ZI densities that occurred in Icy Strait of the year were used for the analysis.

\section{RESULTS}

The density of ZI in Icy Strait varied seasonally and interannually [Fig. 2].

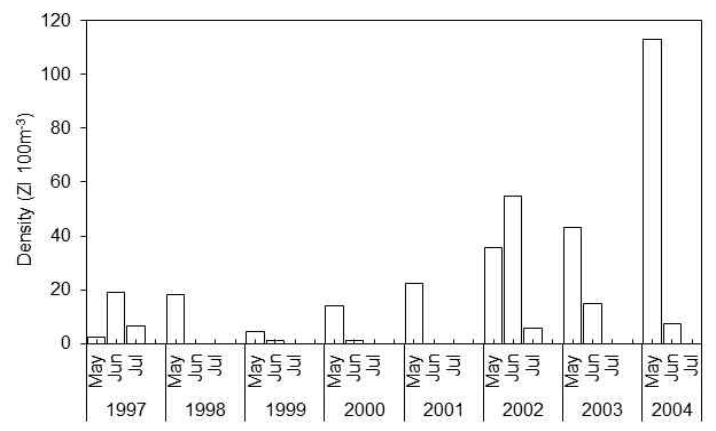

[Fig. 2] Temporal variation of Dungeness crab zoeae I (ZI) in the Icy Strait. ZI were collected in Icy Strait, southeastern Alaska during 1997-2005. Histograms indicate total densities of each month at all stations in the Icy Strait.

The timing of first appearance of $\mathrm{Z} 1$ varied interannually, with larvae first appearing in May in 1998 and 2001; May and June in 1999,
2000, 2003, and 2004; May to July in 1997 and 2002. ZI densities increased after 1999 and decreased in 2004.

Commercial harvests of Dungeness crabs in District 114 and the subdivision $114 \mathrm{C}$ of the $\mathrm{ADF} \& \mathrm{G}$ management area varied interannually [Fig. 3].

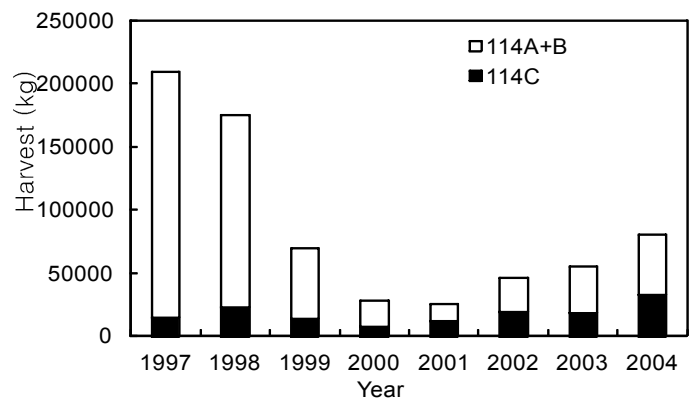

[Fig. 3] Commercial harvests of Dungeness crabs in the Alaska Department of Fish and Game (ADF\&G) registration area, subdivisions $114 \mathrm{~A}+\mathrm{B}$ and subdivision $114 \mathrm{C}$. Sum of the harvests of $114 \mathrm{~A}+\mathrm{B}$ and $114 \mathrm{C}$ makes total harvest of district 114 . Commercial fishery in the district 114 were obtained from Rumble and Bishop (2003) and ADF\&G (Jan Rumble, Douglas, Alaska; Joe Stratman, Petersberg, Alaska). Commercial harvests from the previous April to March of the zooplankton sampling year was regarded as annual harvest.

Commercial harvests in District 114 decreased until 2000 and increased after 2001.

Total densities of ZI summed over all stations in the year were significantly correlated with the total annual commercial harvests in the ADF\&G management area, subdivision 114C (r $=0.75, \mathrm{p}=0.03$; <Table 1>, [Fig. 4]. Total densities of ZI of the year were not significantly related with the commercial harvests in the larger ADF\&G management area, District 114 ( $\mathrm{r}=$ $0.54, p=0.13 ;<$ Table $1>$ ). 
<Table 1> Pearson's product moment correlation coefficients between adult crab abundance and zoea I (ZI) densities of Dungeness crabs. Commercial harvests in Alaska Department of Fish and Game management areas, district 114 and subdivision 114C during 1996-2004 were compared with the total ZI densities during 1997-2005. One-year lag was applied to the analysis: commercial harvests in the previous year and ZI densities in the sampling years. Bold characters indicate significant relationships between adult abundance and ZI densities

\begin{tabular}{c|c|c}
\hline & District 114 & Subdivision 114 C \\
\hline \hline Correlation & $\mathrm{r}=0.54$, & $\mathrm{r}=0.75$, \\
& $\mathrm{p}=0.13$ & $\mathrm{p}=0.03$ \\
\hline
\end{tabular}

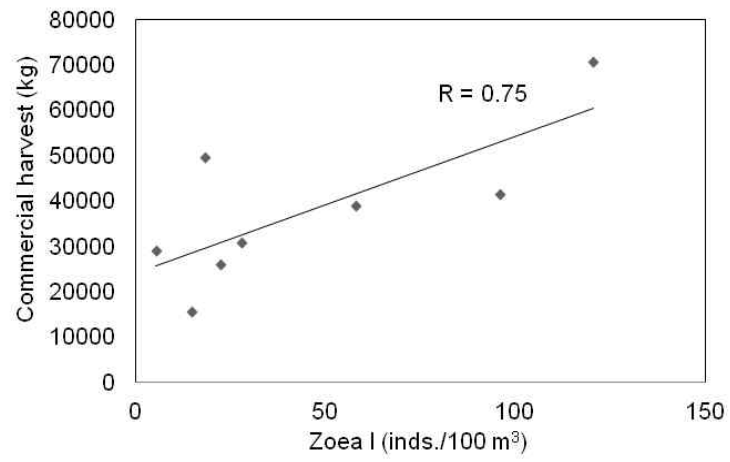

[Fig. 4] Relationship between commercial harvests (spawner potential) and zoeae I (larval production).

\section{DISCUSSION}

The interannual variations in timing of appearance of Dungeness zoeae in this study can be attributed to variations in water temperature during the egg incubation period. The egg incubation period of crabs is extended at colder temperatures, and is shortened at warmer temperatures (Shirley et al., 1987). The egg incubation period of Dungeness crabs at $16.7^{\circ} \mathrm{C}$ is 64 days while that at $9.4^{\circ} \mathrm{C}$ was 123 days (Wild, 1980). The same relationship between water temperature and egg incubation period occurs for other crab species, e.g., red frog crab (Ishikawa et al., 2004); mud crab (Hamasaki, 2003); red king crab (Shirley et al., 1989). Water temperature changes driven by local climate changes affect seasonality and density of local larvae of Dungeness crabs in our study areas (Park \& Shirley, 2008). In the present study, ZI occurred over an extended temporal period, from May to July. In particular, colder temperatures during the egg incubation periods for ZI hatched in 1997 and 2001 (Park \& Shirley, 2008) may have resulted in larval hatching over a longer period of three months. Conversely, warmer temperatures during the egg incubation periods for ZI hatched in 1998, 2003, and 2004 may have resulted in earlier and narrower window of hatching.

Predicting the future populations and understanding current population sizes in all marine species including fish and invertebrates have been the most fundamental issues for the scientists. The relationship between spawner abundances and subsequent recruit populations has been a key research to predict population fluctuations for long time. The relationship may be uncertain because of many reasons: the errors in measurements of both induces also produced the uncertainty of the relationship (Walters \& Ludwig, 1981; Hilborn \& Walters, 1992); marine environmental processes during young juvenile phase drive a fluctuating mortality year to year (Walters \& Collie, 1988; Jarre-Teichmann et al., 2000), namely stochastic 
events of marine environments. Nevertheless, the significant relationship between spawner biomass and recruitment has been evidenced in various species and locations. Myers \& Barrowman (1996) reviewed 364 spawner- recruitment time series and decided that spawner abundance was related with recruitment, particularly that when fish stocks decreased to critically low level: recruitments are proportional to the spawning stocks. Environmental forcing and density -dependent recruitment were related with the population fluctuations in Dungeness crab in the coast of California, Oregon and Washington (Johnson et al., 1986; Hobbs et al., 1992; Botsford \& Hobbs, 1995). Dungeness crabs and salmon species in the Oregon and Washington coasts were covaried with the physical oceanographic conditions (Botsford \& Lawrence, 2002). Dungeness crab populations varied with atmospheric forcing by limiting returning larvae (Shanks and Roegner, 2007).

Because egg or larval productions is an index of recruitment potential, larval abundance has been regarded an estimating larval recruitment and spawning population sizes (Sutherland, 1990; Hurlbut, 1992; Marshall et al., 1998; Crean et al., 2010). In particular, larval abundance was proposed as a relevant predictor of recruitment in endemic fish population but not for non-endemic species at a high latitude coral reef (Crean et al., 2010). Environmental conditions within local habitats affect recruitment mechanisms (Levin, 1998; MacKenzie et al., 2003). The relationship between spawners and recruiters varied with habitat sizes, further carrying capacity in aquatic ecosystems (MacKenzie et al., 2003).

District 114 covers all of Cross Sound and many small bays and estuaries near Cross
Sound, Glacier Bay and Icy Strait, and areas covering the area from Excursion Inlet and Hoonah to Upper Chatham Strait (shaded area in Fig. 1), a linear distance of several hundred $\mathrm{km}$. The weak relationship between the commercial harvest in District 114 and the total ZI densities in Icy Strait may have resulted from larval dispersion into areas not sampled. However, early stage larvae are found relatively near the parental populations (Lough, 1976; Reilly, 1983; Bas et al., 2009). In particular, ZI occur within tens of kilometers from hatching locations (Lough, 1976; Reilly, 1983). The strong relationship between total ZI densities and commercial harvests in subdivision $114 \mathrm{C}$ reflects larval production of local populations within a smaller geographical area. A decrease in the robustness of the relationship at greater distances from hatching areas or at distances further from the plankton sampling area as a result of dispersion and losses resulting from larval mortality should be expected. Additionally, increased loss of later larval stages to the many possible sources of larval mortality (e.g., starvation, predation, disease, etc.) would be expected, thereby decreasing the expectation of meaningful relationships between larval and adult abundances. The early larval stages have less time for these processes to affect abundance and a more robust relationship might be expected. A robust relationship between adult and larval occurred within the smaller subdivision 114C which contained our zooplankton sampling sites than in the more expansive District 114.

Our research proposes that ZI density is an indicator of population abundance and suggests additional research is warranted to confirm the relationship between the abundance of early 
stage larvae (particularly ZI) and adult Dungeness crabs.

\section{ACKNOWLEDGEMENTS}

I thank the researchers of the Ted Stevens Marine Research Institute, NMFS, NOAA for larval Dungeness collections and ADF\&G personnel for harvest data of Dungeness crab. Also, I thank Dr. Shirley for careful reviewing the paper.

\section{REFERENCES}

Bas, C., Tomas, L., Spivak, E., \& Schejter, L.(2009). Larval dispersion of the estuarine crab Neohelice granulata in coastal marine waters of the southwest Atlantic, Estuarine, Coastal and Shelf Science, 83, 569 576.

Botsford, L.W., \& Hobbs, R.C.(1995). Recent advances in the understanding of cyclic behavior of Dungeness crab (Cancer magister) populations, Proceedings of ICES Marine Science Symposium, 199, 157 166 .

Botsford, L.W., \& Lawrence, C.A.(2002). Patterns of co-variability among California Current chinook salmon, coho salmon, Dungeness crab, and physical oceanographic conditions, Progress in Oceanography, 53, 28 3 305 .

Cleaver, F.C.(1949). Preliminary results of the coastal crab (Cancer magister) investigation, Washington Department of Fisheries, Biological Report, 49a, 49 82 .

Crean, A.J., Swearer, S.E., \& Patterson, H. M.(2010). Larval supply is a good predictor of recruitment in endemic but not non-endemic fish populations at a high latitude coral reef, Coral Reefs, 29, 137 143.

Gotshall, D. W.(1978). Northern California Dungeness crab, Cancer magister, movements as shown by tagging, California Department of Fish and Game, 64, 234 254.

Hamasaki, K.(2003). Effects of temperature on the egg incubation period, survival and developmental period of larvae of the mud crab Scylla serrata (Forskal) (Brachyura: Portunidae) reared in the laboratory, 219, 56 $1 \sim 572$.

Hankin, D.G., Butler, T.H., Wild, P.W., \& Xue, Q.L.(1997). Does intense fishing on males impair mating success of female Dungeness crabs? Canadian Journal of Fisheries and Aquatic Sciences, 54, 655 669.

Hart, J.F.(1982). Crabs and their relatives of British Columbia. Provincial Museum Handbook vol. 40. British Columbia, Canada.

Hilborn, R., \& Walters, C.J.(1992). Quantitative fisheries stock assessment: choice, dynamics and uncertainty, Chapman and Hall, New York, U.S.A.

Hobbs, R.C., Botsford, L.W., \& Thomas, A. (1992). Influence of hydrographic conditions and wind forcing on the distribution and abundance of Dungeness crab, Cancer magister, larvae. Canadian Journal Fisheries and Aquatic Sciences, 49, 1379 1388.

Hurlbut, C.J.(1992) Larval release and supply predict temporal variation in settlement of a colonial ascidian, Marine Ecology Progress Series, 80, 215 219 .

Ishikawa, T., Hamasaki K., \& Hamada, K. (2004). Egg size and relationship between seawater temperature and egg incubation period of the red frog crab Ranina ranina (Decapoda: Raninidae) reared in the laboratory, Bulletin of Japanese Society of Fisheries Sciences, 70, 343 347.

Jamieson, G.S., \& Armstrong, D.A.(1991). Spatial and temporal recruitment patterns of Dungeness $\mathrm{crab}$ in the northeast Pacific, Memorial of Queens Museum, 31. 365 381.

Jamieson, G.C., \& Phillips, A.C.(1988), of Cancer crab ( $C$. magister and $C$ oregonensis) megalopae off the west coast of Vancouver Island, British Columbia. Fishery Bulletin, 86, $525 \sim 542$.

Jarre-Teichmann, A., Wieland, K., MacKenzie, 
B.R., Hinrichsen, H.H., Plikshs, M., \& Aro, E.(2000) Stock-recruitment relationships for cod (Gadus morpha callarias L.) in the central Baltic Sea incorporating environmental variability, Archive of Fishery and Marine Research, 48, 97 123 .

Jensen, G.C.(1995). Pacific coast crabs and shrimps. Monterey, California: Sea Challenger.

Johnson, D.F., Botford, L.W., Methot, Jr, R. D., \& Wainwright, T.C.(1986) Wind stress and cycles in Dungeness crab (Cancer magister) catch off California, Oregon, and Washington, Canadian Journal of Fisheries and Aquatic Sciences, 43, 838 $\sim 845$.

Koeneman, T.M.(1985). A brief review of the commercial fisheries for Cancer magister in southeast Alaska and Yakutat waters, with emphasis on recent seasons. Proceedings of symposium on Dungeness crab biology and management, University of Alaska, Sea Grant College Program Report 85-3, 61 $\sim 83$.

Largier, J.L.(2003). Considerations in estimating larval dispersal distances from oceanographic data, Ecological Applications 13(1), 571 589.

Levin, P.S.(1998). The significance of variable and density-dependent post-recruitment mortality in local populations of reef fishes, Australian Journal of Ecology, 23, 246 51.

Levin, L.A.(2006). Recent progress in understanding larval dispersal: new directions and digressions, Integrative and Comparative Biology, 46(3), 282 297.

Lipcius, R.N., \& Stockhausen, W.T.(2002). Concurrent decline of the spawning stock, recruitment, larval abundance, and size of the blue crab Callinectes sapidus in Chesapeake Bay, Marine Ecology Progress Series, 226, 45 61.

Lough, R.G.(1976). Larval dynamics of the Dungeness crab, Cancer magister off the central Oregon coast, 1970-71.Fishery Bulletin, 74, 353 375.

MacKenzie, B.R., Myers, R.A., \& Bowen K.G. (2003). Spawner-recruit relationships and fish stock carrying capacity in aquatic ecosystems, Marine Ecology Progress Series, 248, 209
220.

Marshall, C.T., Kjesbu, O.S., Yaragina, N.A., Solemdal, P., \& Ulltang, Ø.(1998). Is spawner biomass a sensitive measure of the reproductive and recruitment potential of Northeast Arctic cod? Canadian Journal of Fisheries and Aquatic Sciences, 55, 1766 1783.

McConnaughey, R.A., Armstrong, D.A., Hickey, B.M., \& Gunderson, D.R.(1992). Juvenile Dungeness crab (Cancer magister) recruitment variability and oceanic transport during the pelagic larval phase. Canadian Journal of Fisheries and Aquatic Sciences, 49, 2028 2044.

McConnaughey, R.A., Armstrong, D.A., Hickey, B.M., \& Gunderson, D.R.(1994). Interannual variability in coastal Washington Dungeness crab (Cancer magister) populations: larval advection and the coastal landing strip, Fisheries Oceanography, 3, 22 38.

McKelvey, R., Hankin, D., Yanosko, K., \& Snygg, C.(1980). Stable cycles in multistage recruitment models: an application to the northern California Dungeness crab (Cancer magister) fishery, Canadian Journal of Fisheries and Aquatic Sciences, 37, 2323 2345.

Methot, R.D., \& Botsford, L.W.(1982). Estimated preseason abundance in the California Dungeness crab (Cancer magister) fisheries, Canadian Journal of Fisheries and Aquatic Sciences, 39, 1077 1083.

Myers, R.A., \& Barrowman, N.J.(1996). Is fish recruitment related to spawner abundance? Fishery Bulletin, 94, 707 724.

Park, W.(2007). Advection and retention of larval Dungeness crab Cancer magister in Glacier Bay and adjacent areas, $\mathrm{PhD}$ dissertation, University of Alaska Fairbanks, AK.

Park, W., \& Shirley, T.C.(2005). Diel vertical migration and seasonal timing of the larvae of three sympatric cancrid crabs, Cancer spp., in southeastern Alaska, Estuaries, 28, 266 273.

Park, W., \& Shirley, T.C.(2008). Variations of abundance and hatch timing of Dungeness crab larvae in southeastern Alaska: 
Implications for climate effect, Animal Cells

Park W., Douglas D.C. and Shirley T.C.(2007) North to Alaska: evidence for conveyor belt transport of Dungeness crab larvae along the west coast of the United States and Canada, Limnology and Oceanography, 52, 248 256.

Poole, R.L.(1966). A description of the laboratory-reared zoeae of Cancer magister Dana, and megalopae taken under natural conditions (Decapoda, Brachyura), Crustaceana, 11, 83 97.

Reilly, P.N.(1983). Dynamics of the Dungeness crab, Cancer magister, larvae off central and northern California. In Wild P.W. and Tasto R.N. (Eds) Life History, Environment, and Mariculture Studies of the Dungeness crab, Cancer magister, with Emphasis on the Central California Fishery Resource, California Department of Fish and Game Fishery Bulletin, 172, 57 84 .

Rumble, J., \& Bishop, G.(2003). Report to the Board of Fisheries, Southeast Alaska Dungeness crab fisheries, Alaska Department of Fish and Game Regional Information 1J02-45.

Shanks, A.L., \& Roegner, G.C.(2007). Recruitment limitation in Dungeness crab populations is driven by variation in atmospheric forcing, Ecology, 88, 1726 1737.

Shirley, S.M., Shirley, T.C., \& Rice, S. A.(1987). Latitudinal variation in the Dungeness crab, Cancer magister. zoeal morphology explained by incubation temperature, Marine Biology, 95. $371 \sim 376$.

Shirley, S.M., Shirley, T.C., \& Korn, S.A.(1989). Incubation period, molting and growth of female red king crabs: effects of temperature, In Melteff B. R.(Ed) Proceedings of International Symposium King and Tanner Crabs, Anchorage, Alaska, pp 51 63.

Smith, B.D., \& Jamieson, G.S.(1989). Exploitation and mortality of male Dungeness crab (Cancer magister) near Tofino, British Columbia, Canadian Journal of Fisheries and Aquatic Sciences, 46, 1609 1914. and Systems, 12, 287-295.

Smith, B.D., \& Jamieson, G.S.(1991). Movement, spatial distribution, and mortality of male and female Dungeness crab Cancer magister near Tofino, British Columbia, Fishery Bulletin, $89,137 \sim 148$.

Snow, C.D., \& Wagner, E.J.(1965). Tagging of Dungeness crabs with spaghetti and dart tags, Fish Commission of Oregon Research Briefs, 11, 5 13.

Stone, R.P., \& O'Clair, C.E.(2001). Seasonal movements and distribution of Dungeness crabs Cancer magister in a glacial southeastern Alaska estuary, Marine Ecology Progress Series, 214, 167 176.

Sutherland, J.P.(1990). Recruitment regulates demographic variation in a tropical intertidal barnacle. Ecology, 71, 955 972.

Taggart, S.J., Shirley, T.C., O'Clair, C.E., \& Mondragon, J.(2004). Dramatic increase in the relative abundance of large male Dungeness crabs, Cancer magister, following closure of commercial fishing, American Fisheries Society Symposium, 42, 243 253 .

Walters, C.J., \& Collie, J.S.(1988). Is research on environmental factors useful to fisheries management? Canadian Journal of Fisheries and Aquatic Sciences, 45, 1848 1854.

Walters, C.J., \& Ludwig, D.(1981). Effects of measurement errors on the assessment of stock-recruitment relationships, Canadian Journal of Fisheries and Aquatic Sciences, 38, 704 710.

Wild, P.W.(1980). Effects of seawater temperature on spawning, egg development, hatching success, and population fluctuations of the Dungeness crab, Cancer magister, California Cooperative Ocean and Fisheries Investigation Report, 21, 115 120 .

- 논문접수일 : 2011년 10월 27일

- 심사완료일 : 1차 - 2011년 11월 20일

- 게재확정일 : 2011년 11월 30일 